\title{
A REVIEW ON THE USE OF L1 IN FOREIGN LANGUAGE CLASSROOMS
}

Peng Zilian ${ }^{\mathrm{i}}$

Yangtze University,

China

\begin{abstract}
:
This review aims to provide a comprehensive perspective on the use of first language (L1) in foreign language classrooms by reviewing 15 empirical studies. This review found that the focuses of those studies can be categorized from five aspects: (1) extent of L1 use, (2) the purpose of L1 use, (3) factors influencing teachers' use of L1, (4) attitudes and identities related to L1 use, and (5) the effectiveness of L1 use on second language (L2) learning. Methods for research on this area and directions for future research are suggested.
\end{abstract}

\section{摘要 :}

本文旨在通过对 15 篇实证研究的回顾, 对外语课堂中母语的使用提供一个全面的视角。本文主要 发现, 这些研究的主题可以分为五类: (1)使用母语的程度, (2) 使用母语的目的, (3) 影响教师使用母 语的因素，(4) 矢于母语使用的态度和身份转变，以及 (5) 母语使用对外语学习的影响。基于以上发 现本文总结了该领域的研究方法, 指明了未来的研究方向。

Keywords: L1/L2 use; code-switching; foreign language education

\section{Introduction}

The on-going debate of L1 use in foreign language education exists for a long time. Empirical studies on this topic have continued to investigate various aspects of L1 use in foreign language education. Therefore, it is critical for researchers and educators to have an updated review, which integrates separate and discrete findings at the global level.

This review aims to provide a possible direction for future research on the use of L1 in foreign language classrooms by reviewing 15 empirical studies closely relevant to this topic. 12 articles were snowballed according to Sali's (2014) research from those published on international journals in 2014 to 2020, 3 articles were searched from those published on core journals or CSSCI in CNKI with the keywords as follows: L1, first language, mother tongue, and code-switching.

i Correspondence: email zilian.peng@qq.com 
To minimize possible confusion, L1 was defined as a student's native language, the mother tongue, or own language (Hall \& Cook 2012). L2 was defined as the target language, the foreign language, or the second language learned in a classroom. And code-switching was defined as the switching between L1 and L2 by the teacher or students while communicating in foreign language classrooms.

All selected articles were categorized into the following five areas according to their research focuses: (1) extent of L1 use, (2) the purpose of L1 use, (3) factors influencing teachers' use of L1, (4) attitudes and identities related to L1 use, and (5) the effectiveness of L1 use on L2 learning. This categorization was established on the basis of Shin et al.'s (2020) review, and the coding for category was conducted by the author alone.

\section{An overview of findings on L1 use}

\subsection{Extent of L1 use}

Of the 15 reviewed studies, 7 dealt with the extent of L1 use, and inconsistent findings appeared.

As for the use of L1 in foreign language classrooms, Wang (2003) found that the use of L1 in foreign language classrooms was quite common, while Adriosh \& Razi (2019) found that L1 was occasionally used in the classroom they observed. The investigation (e.g. Xie, 2011; Izquierdo et al., 2016; Chen, 2014) on teachers' use of L1 in foreign language classrooms suggests that teachers' code-switching behavior and their overreliance on L1 were not uncommon, which is contradictory with the results in Yuvayapan's (2019) research that teachers did not frequently use L1. Conclusion related to teachers' use of L1 could be draw that teachers used L1 to different degrees as indicated in the study of Tekin \& Garton (2020).

The inconsistency of their findings might have been influenced by the context the investigation conducted, the sample size of participants and the choice of methods (see Table 1). For example, the investigation of Xie (2011) and Chen (2014) was conducted in China, while Yuvayapan's (2019) research was under the Turkish context, as a result of which inconsistency appears in their findings.

\subsection{The purpose of $\mathrm{L} 1$ use}

9 of the studies examined the purpose of L1 use in foreign language classrooms and Sali's (2014) framework of the purpose of $\mathrm{L} 1$ use is regarded as the most comprehensive one, which contains the purposes mentioned in other studies, and thus this paper presents Sali's framework in Figure 1 as a reference to future studies.

In academic terms, explaining aspects of English (Xie, 2011; Chen, 2014; Izquierdo et al., 2016; Adriosh \& Raz1, 2019; Köylü, 2020), eliciting (Ong \& Tajuddin, 2020; Tekin \& Garton, 2020), reviewing (Chen, 2014; Adriosh \& Razl, 2019), translating words and sentences (Xie, 2011; Chen, 2014), talking about learning (Ong \& Tajuddin, 2020), and checking comprehension (Chen, 2014) are included. L1 can also be used for more effective classroom management (Ong \& Tajuddin, 2020; Wilden \& Porsch, 2020; Köylü, 2020). In addition, L1 can be used to establish rapport (Xie, 2011; Adriosh \& Razi, 2019) and provide feedback (Tekin \& Garto, 2020) as well. 
Generally speaking, L1 plays a crucial role in foreign language classrooms. Teachers realize various teaching purposes through the use of L1, but what negative effects will be brought by the use of L1 in foreign language classrooms remains unexplored.

\subsection{Factors influencing teachers' use of L1}

8 of the studies examined factors that influence teachers' language choice, and the major categories of factors that determine L1 use in foreign language classrooms were: (1) studentrelated factors, (2) teacher-related factors, and (3) contextual factors.

Regarding student-related factors, the studies found three factors which heavily influence teachers' language choice: the students' L2 proficiency (Xie, 2011; Sali, 2014; Chichon, 2018; Tekin \& Garton, 2020; Köylü, 2020), age (Chichon, 2018) and motivation of L2 learning (Chichon, 2018).

As for teacher-related factors, five factors were found to affect teachers' use of L1: teachers' L2 proficiency (Xie, 2011; Wilden \& Porsch, 2020), language learning experiences (Xie, 2011; Raman \& Yiğitoğlu, 2018), pre-service education (Raman \& Yiğitoğlu, 2018), prior teaching experiences (Chichon, 2018) and the need to socialize and communicate with learners (Köylü, 2020). As Wilden \& Porsch (2020) indicated that teachers with a higher formal qualification tend to assess their L2 proficiency higher and claim to use the L2 more often in the primary EFL classroom. In contrast, teachers with a lower formal qualification tend to assess their L2 proficiency lower and claim to use the L1 more frequently in the L2 classroom.

Seven contextual factors were found to influence teachers' use of L1, namely, the expectations of their institutions, colleagues and parents of their students (Yuvayapan, 2019), types of classroom activities (Sali, 2014), the context of teaching (Raman \& Yiğitoğlu, 2018), institutional policies (Raman \& Yiğitoğlu, 2018), types of teaching content (Chichon, 2018; Köylü, 2020; Tekin \& Garton, 2020), curricular needs (Köylü, 2020; Tekin \& Garton, 2020), and time constraints (Köylü, 2020; Tekin \& Garton, 2020).

\subsection{Attitudes and identities related to L1 use}

A total of 6 studies (e.g. Wang, 2003; Sali, 2014; Chichon, 2018; Yuvayapan, 2019; Adriosh \& Raz1, 2019; Gallagher, 2020) explored teacher attitudes towards L1 use in foreign language classrooms. Wang (2003) and Adriosh and Razı (2019) also focus on learners' voices. Both teachers and students held positive towards the use of L1 and recognized the benefits of the L1, except that teachers in Gallagher's (2020) research tend to have stronger views against using the L1 in multilingual contexts and to be more tolerant and flexible of this phenomenon in shared-L1 contexts and they believe that an L2-only approach facilitates a superior form of language learning.

Among the 15 studies, only Raman \& Yiğitoğlu's (2018) research paid attention to teachers' identities to L1 use in foreign language classrooms, which shows that teachers were taking multiple identity positions when justifying their code-switching practices being their personal identities, namely, non-native English teacher identities, language learner identities and linguistic identities. Ige (2010, p. 3047) states that "identity in many respects is shaped by language and conversely, language choices may relate to identity". Additionally, Pable et al. (2010) claim that 
"identities are commonly believed to shift as one shifts code, each shift being potentially meaningful as to which identity speaker wishes to foreground, as required by a particular situation".

\subsection{The effectiveness of L1 use on L2 learning}

Little attention has been paid to the effectiveness of L1 on L2 learning among the 15 reviewed studies, only Zhu \& Vanek (2015) found that a higher student response frequency as well as a longer mean utterance length in code-switching classes than L2-only classes. The participants were divided into two groups: two code-switching classes formed 'the experimental group', and two L2-only classes were 'the control group'. This division with L2-only classes as a control comparative baseline aims to detect whether or not the absence of L1 use coincides with different degrees of students' classroom involvement.

\section{Discussion}

\subsection{Methods used for research on L1 use}

Investigation of the extent of L1 use in foreign language classrooms is usually conducted by classroom observations. According to Dornyei (2007), classroom observation is "invaluable for providing descriptive contextual information about the setting of the targeted phenomenon" (p. 185). Clause-utterance counts (e.g. Izquierdo et al., 2016) generally have been employed as a feasible way to analyze quantity of L1 use in the video-recorded or audio-recorded data.

Stimulated recall is commonly used to probe into teachers' purposes of L1 use. Stimulated recall is "a technique in which the researcher records and transcribes parts of a lesson and then gets the teacher...to comment on what was happening at the time that the teaching and learning took place" (Nunan, 1992, p. 94).

Pre-class or post-class semi-structured interviews are often used as a supplement to classroom observations to further understand teachers' beliefs and behaviors. Through interviewing, "We can learn what people perceived and how they interpreted their perceptions. We can learn how events affected their thoughts and feelings. We can learn the meanings to them of their relationships, their families, their work, and their selves. We can learn about all the experiences, from joy through grief, that together constitute the human condition" (Weiss, 1995, p.16). In the reviewed articles, interviews are adopted to identify the factors affecting teachers' use of L1 and teachers and students' attitudes towards L1 use, as well as teachers' identities related the used of L1.

The effectiveness of L1 use on L2 learning is often conducted with experimental research designs. For example, Zhu \& Vanek (2015) set an experimental group to test if L1 use would facilitate classroom engagement. According to Creswell (2002), "In an experiment, you test an idea (or practice or procedure) to determine whether it influences an outcome or dependent variable. You first decide on an idea with which to "experiment," assign individuals to experience it (and have some individuals experience something different), and then determine whether those who experienced the idea (or practice or procedure) performed better on some outcome than those who did not experience it" ( $\mathrm{p}$. 295). 


\subsection{Direction for future research}

Since only 2 out of 15 studies have investigated students' perspectives on L1 use, it would be important to get learners' perspectives on L1 use and listen to their voices, actively involving them in research and getting their "unique insights", a point also emphasized by Tekin \& Garton (2020). Learners' perspectives on L1 use may provide researchers a deeper understanding of their needs on the foreign language learning, as a result of which can facilitate teachers' judicious use of L1.

Among the reviewed 15 studies, only Zhu \& Vanek (2015) explored the effects of teachers' code-switching behavior in foreign language classrooms. Both the L2-only principle and the use of L1 aim to help learners acquire the target language, but how L1 use would affect learners' L2 learning is hardly investigated. It could be a worthy endeavor to conduct experimental research to measure the effectiveness of L1 use on learners' L2 acquisition.

Finally, when to use L1 and how much L1 should be used in foreign language classrooms perplexed foreign language teachers. Therefore, action research planning teaching strategies and practices for the judicious use of L1 is needed, which is also recommended in the review of Shin et al. (2020).

\section{Conclusion}

\subsection{Summary}

The purpose of this paper is to provide references for future studies relevant to L1 use in foreign language education by reviewing 15 empirical studies on this field. To sum up, a lot attention has been paid to L1 use in foreign language classrooms. Research in this field involves (1) extent of L1 use, (2) the purpose of L1 use, (3) the factors influencing teachers' use of L1, (4) attitudes and identities related to L1 use, and (5) the effectiveness of L1 use on L2 learning. Through the review, it is found that teachers' use of the target language in foreign language teaching is important, but L1 also plays a critical role in foreign language classrooms. No matter following the principle of L2-only teaching or allowing the use of L1, the fundamental purpose of teachers is to help students acquire the target language. However, there are many factors influencing teachers' use of L1 in foreign language classrooms. Although the teachers and students mostly held a positive attitude towards the use of L1 in foreign language classrooms, they do not know when and how much L1 should be used in foreign language classrooms, and research on the impact of using L1 on students' foreign language learning is also needed.

\subsection{Limitation of this review}

This review is limited by its small scale, namely, merely reviewing 15 empirical studies on L1 use in foreign language classrooms, among which 12 articles were snowballed according to Sali's (2014) research from those published on international journals in 2014 to 2020, 3 articles were searched from those published on core journals or CSSCI in CNKI with the keywords as follows: L1, first language, mother tongue, and code-switching. Therefore, abundant studies on this field may have been neglected due to the search strategy. In addition, the coding for the category was conducted by the author alone, and thus subjectivity exists. Future research can expand the scope 
of literature on the basis of this review in order to have a more comprehensive understanding of this field.

Table 1: An overview of the 15 reviewed studies

\begin{tabular}{|l|l|l|l|}
\hline Study & Context & Participants & Methods \\
\hline Wang (2003) & China' secondary school & 498 students; 10 teachers & Questionnaires \\
\hline Xie (2011) & China; university & 3 teachers of English majors & Observations; stimulated recall \\
\hline Chen (2014) & China; university & $\begin{array}{l}40 \text { teachers of non-English } \\
\text { majors }\end{array}$ & Observations; stimulated recall \\
\hline Sali (2014) & $\begin{array}{l}\text { Turkey; public secondary } \\
\text { school }\end{array}$ & 3 teachers & Observations, interviews \\
\hline Zhu \& Vanek (2015) & China; secondary school & 4 teachers; 4 classes & Observations, interviews \\
\hline Izquierdo et al. (2016) & Mexico; secondary school & 9 teachers & Observations \\
\hline Chichon (2018) & Japan, university & 9 English-native teachers & Questionnaires; group interviews \\
\hline $\begin{array}{l}\text { Raman \& Yiğitoğlu } \\
\text { (2018) }\end{array}$ & Cyprus; university & 3 novice teachers & Observations; stimulated recall \\
\hline Adriosh \& Raz1 (2019) & Libya; university & 6 teachers; 24 students & Observations; interviews \\
\hline Yuvayapan (2019) & $\begin{array}{l}\text { Turkey; state \& private } \\
\text { schools }\end{array}$ & 50 (5 ; 10 teachers & $\begin{array}{l}\text { Questionnaires; observations; } \\
\text { interviews }\end{array}$ \\
\hline Gallagher (2020) & Ireland & 24 teachers & Interviews \\
\hline Köylü (2020) & Turkey; university & 155 (3) teachers & Questionnaires; interviews \\
\hline Ong \& Tajuddin (2020) & $\begin{array}{l}\text { Malaysia; rural secondary } \\
\text { school }\end{array}$ & 1 teacher & Observations \\
\hline Tekin \& Garton (2020) & Turkey; primary school & 5 teachers & $\begin{array}{l}\text { Observations; interviews (pre \& } \\
\text { post) }\end{array}$ \\
\hline Wilden \& Porsch (2020) & Germany; primary school & 844 teachers & Questionnaires \\
\hline
\end{tabular}

\begin{tabular}{|l|}
\hline \multicolumn{1}{|c|}{ Academic } \\
\hline - Explaining aspects \\
of English \\
- Eliciting \\
- Reviewing \\
- Translating words \\
and sentences \\
- Talking about \\
learning \\
- Checking \\
comprehension \\
\hline
\end{tabular}

\begin{tabular}{|l|}
\hline \multicolumn{1}{|c|}{ Managerial } \\
\hline - Giving instruction \\
- Managing \\
discipline \\
- Monitoring \\
- Drawing attention \\
\\
\end{tabular}

\begin{tabular}{|l|}
\hline Social/Cultural \\
\hline - Establishing \\
rapport \\
- Drawing upon \\
shared cultural \\
expressions \\
- Praising \\
\\
\end{tabular}

Figure 1: Sali's framework of the purpose of L1 use

\section{Conflict of Interest Statement}

The author declares no conflicts of interests. 


\section{About the Author}

Peng Zilian is currently pursuing her master's degree in the School of Foreign Studies at Yangtze University in Jingzhou, China.

\section{References}

Adriosh, M., \& Razı, Ö. (2019). Teacher's Code Switching in EFL Undergraduate Classrooms in Libya: Functions and Perceptions. SAGE Open, 9(2), 2158244019846214.

Chen, L. (2014). An analysis of functions of teachers' code-switching in College English classrooms. Foreign Language Education in China (Quarterly), 7(4), 70-77.

Chichon, J. P. (2018). An Analysis of Instructors' Perspectives to First Language (L1) Use in Monolingual Japanese University Contexts. Journal of English as an International Language, 13, 100-121.

Creswell, J. W. (2002). Educational research: Planning, conducting, and evaluating quantitative. Upper Saddle River, NJ: Prentice Hall.

Dornyei, Z. (2007). Research Methods in Applied Linguistics. Spain: Oxford University Press.

Gallagher, F. (2020). Considered in context: EFL teachers' views on the classroom as a bilingual space and code switching in shared-L1 and in multilingual contexts. System, 91, 102262.

Hall, G., and G. Cook. (2012). “Own-language Use in Language Teaching and Learning." Language Teaching 45 (3): 271-308.

Ige, B. (2010). Identity and language choice: ‘We equals I'. J. Pragmat. 42(11), 3047-3054.

Izquierdo, J., Martínez, V. G., Pulido, M. G. G., \& Zúñiga, S. P. A. (2016). First and target language use in public language education for young learners: Longitudinal evidence from Mexican secondary-school classrooms. System, 61, 20-30.

Köylü, Z. (2020). Understanding Tertiary Level EFL Instructors' Code-switching Behavior. In book: Pedagogic and Instructional Perspectives in Language Education: The Context of Higher Education (pp.119-138). Publisher: Peter Lang.

Nunan, D. (1992). Research methods in language learning. New York Cambridge University Press.

Ong, J. W., \& Tajuddin, A. A. (2020). Towards a Principled Use of L1-Observing an EFL Teacher's L1 Use in Rural Sabah, Malaysia. International Journal of Learning, Teaching and Educational Research, 19(6).

Pable, A., Marc, H., Christe, N. (2010). Language and social identity: an integrationist critique. Lang. Sci. 32,671-676.

Raman, Y., \& Yiğitoğlu, N. (2018). Justifying code switching through the lens of teacher identities: novice EFL teachers' perceptions. Quality \& Quantity, 52(5), 2079-2092.

Shin, J. Y., Dixon, L. Q., \& Choi, Y. (2020). An updated review on use of L1 in foreign language classrooms. Journal of Multilingual and Multicultural Development, 41(5), 406-419.

Sali, P. (2014). An analysis of the teachers' use of L1 in Turkish EFL classrooms. System, 42, 308318. 
Tekin, S., \& Garton, S. (2020). L1 in the primary English classroom: How much, when, how and why?. Iranian Journal of Language Teaching Research, 8(3), 77-97.

Wilden, E., \& Porsch, R. (2020). Teachers' self-reported L1 and L2 use and self-assessed L2 proficiency in primary EFL education. Studies in Second Language Learning and Teaching, 10(3), 631-655.

Wang, J. (2003). A Facilitator or a Barrier? - A survey on the role of mother tongue in English class. Modern Foreign Language (Quarterly), 26(4), 394-402.

Weiss, R. S. (1995). Learning from strangers: The art and method of qualitative interview studies. Simon and Schuster.

Xie, X. (2011). The amount, purposes and reasons for using L1 in university English-major classrooms. Modern Foreign Language (Quarterly), 34(3), 271-278.

Yuvayapan, F. (2019). Translanguaging in EFL classrooms: Teachers' perceptions and practices. Journal of Language and Linguistic Studies, 15(2), 678-694.

Zhu, X., \& Vanek, N. (2015). Facilitative effects of learner-directed code-switching: Evidence from Chinese learners of English. International Journal of Bilingual Education and Bilingualism, 20(7), 773-787. 
Peng Zilian

A REVIEW ON THE USE OF L1 IN FOREIGN LANGUAGE CLASSROOMS

Creative Commons licensing terms

Author(s) will retain the copyright of their published articles agreeing that a Creative Commons Attribution 4.0 International License (CC BY 4.0) terms will be applied to their work. Under the terms of this license, no permission is required from the author(s) or publisher for members of the community to copy, distribute, transmit or adapt the article content, providing a proper, prominent and unambiguous attribution to the authors in a manner that makes clear that the materials are being reused under permission of a Creative Commons License. Views, opinions and conclusions expressed in this research article are views, opinions and conclusions of the author(s). and European Journal of Literature, Language and Linguistics Studies shall not be responsible or answerable for any loss, damage or liability caused in relation to/arising out of conflicts of interest, copyright violations and inappropriate or inaccurate use of any kind content related or integrated into the research work. All the published works are meeting the Open Access Publishing requirements and can be freely accessed, shared, modified, distributed and used in educational, commercial and non-commercial purposes under a Creative Commons Attribution 4.0 International License (CC BY 4.0).

European Journal of Literature, Language and Linguistics Studies - Volume 5 | Issue 1 | 2021 